\title{
Carbon Storage Potential of Kubayo Forest and Its Implication for Climate Change Mitigation, Bale Zone, Southeastern Ethiopia
}

\author{
Demisie Asfaw ${ }^{1} \quad$ Lemma Tiki $^{2}$ Dejene Worku ${ }^{3 *}$ \\ 1 Robe Preparatory School \\ 2 Ambo University, Department of Natural Resource Management \\ 3 Madda Walabu University, Collage of Natural and Computational Science, Department of Environmental \\ Science
}

\begin{abstract}
Background: Environmental degradation particularly, climate change is currently becoming a horrific and multifaced global phenomenon. Addressing it requires the amalgamation of numerous disciplines and cooperation among nations. Addressing this problem requires the incorporation of numerous disciplines and cooperation among citizens. Forestry development and management can be one of such actions that can contribute to climate change mitigation.

Objective: An investigation was conducted in Kubayo forest, with the objective to estimate carbon stock of the forest in the study area.

Methodology: Aboveground biomass was estimated by using allometric models while belowground biomass was determined based on the ratio of belowground biomass to aboveground biomass factors. The liter layer and soil organic carbon were estimated from the samples taken from the sample plot. In order to collect litter and soil sample data, a total of 63 quadrats, each with the size of $20 \mathrm{~m} \times 20 \mathrm{~m}$ at an interval of $100 \mathrm{~m}$ were laid along the 9 established transects at $200 \mathrm{~m}$ apart. In addition, five quadrats each with the size of $1 \mathrm{~m} \mathrm{x} 1 \mathrm{~m}$ were established at four corners and center of every quadrat.

Data Analysis: The result was analyzed by Microsoft excel, Statistical Package for Social Science (SPSS) software version 20 and Based on the collected data (DBH, fresh and dry weights of litter and soil organic matter), biomasses of each tree species in all sample quadrats were calculated by using developed allometric models.

Result: The findings of the study showed that, the total maximum and minimum carbon stock estimated were 532.57 and 212.30 ton/ha respectively, with the average value of 370.34 ton/ha. The average carbon dioxide sequestered were 1359.15 ton/ha.

Recommendation: The study recommends that, the existing forest management systems should integrate indigenous and scientific methods to play vital role to maximize the mitigation of climate change and global warming
\end{abstract}

Keywords: Kubayo forest, biomass, carbon stock, climate change mitigation.

DOI: $10.7176 / \mathrm{CMR} / 11-9-02$

Publication date: November $30^{\text {th }} 2019$

\section{INTRODUCTION}

Forests contribute to climate change mitigation by removing atmospheric carbon dioxide and storing it in different carbon pools (i.e., biomass, soil, dead organic matter, litter) (IPCC, 2006). Deforestation and forest degradation are important contributors to global greenhouse gas emissions, but if these processes are controlled, forests can significantly contribute to climate change mitigation. It is estimated that $15 \%$ of global greenhouse gas emissions came from deforestation over the period of 2000-2005 (Van der Werf et al, 2009). Moreover, forests comprise an important carbon reservoir, since they store about twice the amount of carbon present in the atmosphere (Canadell, 2008). Terrestrial ecosystems could also be a major sink with the potential to offset from $2 \%$ to $30 \%$ of expected emissions during this century (Beerling, 2004).

Greenhouse gases (GHG) emitted into the atmosphere by human activities were reported as a cause for an increment of global mean temperature of approximately $0.74^{\circ} \mathrm{C}\left(1.33^{\circ} \mathrm{F}\right)$ over the past century (IPCC, 2007).

Estimates of projected temperature increases over the $21^{\text {st }}$ century range between approximately $1.8^{\circ} \mathrm{C}$ and $4.9^{\circ} \mathrm{C}\left(3.2^{\circ} \mathrm{F}\right.$ and $\left.8.8^{\circ} \mathrm{F}\right)(\mathrm{IPCC}, 2007)$. Primary anthropogenic GHGs will be contributing to increase of carbon dioxide $\left(\mathrm{CO}_{2}\right)$, Methane $\left(\mathrm{CH}_{4}\right)$, and nitrous oxide $\left(\mathrm{N}_{2} \mathrm{O}\right)$. Future projections indicate temperature increases generally consistent with historical trends, with the greatest temperature increases over land and at high northern latitudes and less warming over the southern hemisphere (Kang et al., 2008).

The melting of ice, glaciers and rising of sea levels is the main cause of global temperature and this leads to a significant change in the world's climatic pattern (IPCC, 2007; Lasco et al., 2006). Carbon sequestration by forests is one way to mitigate GHG emissions by offsetting losses through removal and storage of carbon. Forests and other ecosystems generally act as carbon sinks because, through photosynthesis, growing plants 
remove carbon dioxide from the atmosphere and store it (UNFCCC, 2009).

Carbon taking and storing in biomass and soils in the forest sector has gained widespread acceptance as a potential greenhouse gas mitigation approach (Gibbs et al., 2007). Much of the observed warming of the earth's surface is believed to be due to increased concentrations of greenhouse gases in the earth's atmosphere, which have altered the earth's radioactive balance, i.e., the 'greenhouse effect' (IPCC, 2001). The main greenhouse gases are carbon dioxide $\left(\mathrm{CO}_{2}\right)$, methane $\left(\mathrm{CH}_{4}\right)$, and nitrous oxide $\left(\mathrm{N}_{2} \mathrm{O}\right)$, of which $\mathrm{CO}_{2}$ is by far the most important (accounting for 65 percent of the greenhouse effect). Most of the $\mathrm{CO}_{2}$ emissions derived from human activity are the result of fossil fuel combustion ( 76 percent of the total). Tropical deforestation and forest degradation account for an estimated 23 percent, and the remaining 1 percent comes from cement manufacture (FAO, 1998).

Forests resources are known to play an important role in regulating the global climate. They play a key role in both sinks and sources of carbon dioxide. Globally, forests act as a natural storage for carbon, contributing approximately $80 \%$ of terrestrial above-ground and $40 \%$ of terrestrial belowground biomass carbon storage (Kirschbaum, 1996). Most terrestrial biomass carbon storage is in tree trunks, branches, foliage, and roots which is often called biomass. Consequently, forest biomass is an important element in the carbon cycle, specifically in carbon sequestration. Forests used to quantify pools and fluxes of greenhouse gases (GHGs) from the terrestrial biosphere associated with land use land cover changes (Cairns et al., 2003). Moreover, forests are thought to provide a more cost-effective means of reducing global $\mathrm{CO}_{2}$ emissions than other sectors (IPCC, 2007).

Climate change and variability impacts will affect everyone, particularly Ethiopia, as we are situated in the sub-Saharan Africa, where countries are already vulnerable to climate variability and have the least capacity to respond (IPCC, 2007). Ethiopia can benefit from global initiatives from clean energy development and reduced deforestation. Ethiopia is experiencing the effects of climate change such as an increase in average temperature and change in rainfall patterns. The Government of the Federal Democratic Republic of Ethiopia has therefore initiated Climate-Resilient Green Economy (CRGE), which promotes protecting and re-establishing forests for their economic, ecosystem services and carbon storage in 2011 (FDRE, 2011).

Forests have vital ecosystem service in soil and biodiversity conservation and mitigation of climate change, they are under heavy pressure: they are cleared for fire wood, expansion of cash crops and new settlements and apparently are shrinking overtime. Deforestation, forest degradation, forest fire and burning of fossil fuel are playing a significant role in producing the greenhouse gases (IPCC, 2000). Ethiopian People particularly in the rural areas of the country are highly dependent on forest resources to fulfill their basic needs such as fuel wood for cooking, heating, foliage for livestock, and timber for shelter and non-timber products for medicine. Environmental degradation and deforestation have been taking place for many years in the country. Especially during the last century, Ethiopia's forest and woodlands have been declining both in size (due to deforestation) and quality (due to degradation) (EFAP, 1994).

Unlike the developed countries, Ethiopia does not have well organized and efficient carbon inventories and data bank to monitor and enhance carbon sequestration potential of different forests. Even though this study covers small area when compared to the Ethiopian forest coverage, it is important for contributing sustainable forest management which helps to mitigate the raising tides of climate change. Therefore, this study has an aim to fill the aforementioned gap by estimating the carbon sequestration potential of Kubayo forest in Goloha District of Bale Zone between 2018 and 2019. Hence, it will provides information on the current status of Kubayo forest and address the role of this forest in climate change mitigation by reducing emission of GHGs from atmosphere.

\subsection{Objectives of the Study}

The general objective of this study was to estimate carbon stock of Kubayo forest. Specifically the study was focused to estimate carbon sequestered in above and below ground biomass (in litter and soils) and to determine the carbon stock variations along altitudinal gradients and under different aspects

\section{MATERIALS AND METHODS}

\subsection{Description of the Study Area}

This study was conducted in Kura Wada kebele, Gololcha district which is Located in the Oromia National Regional State of Bale Zone. Kubayo forest was located at about $15 \mathrm{~km}$ from Jara town on Dire Shek Husien Road. It is also $117 \mathrm{~km}$ from Robe town towards east direction and $547 \mathrm{~km}$ from Addis Ababa. Kubayo forest is one of the remnant dry afro-montane forests in South East parts of Ethiopia. It has an altitudinal gradient of ranging from 1923 to $2225 \mathrm{~m}$ above sea level with the geographical location of $7^{0} 29^{\prime} 23^{\text {ee }} \mathrm{N}$ to $7^{0} 34^{\prime} 52^{\prime \prime} \mathrm{N}$ and $40^{0} 39^{\prime} 56^{\prime \prime} \mathrm{E}$ to $40^{0} 45^{\prime} 55^{\prime \prime} \mathrm{E}$. According to the Gololcha District Agriculture and Rural Development Office (GDARDO), the forest covers a total area of 153 ha and it is a home for a variety of fauna. 


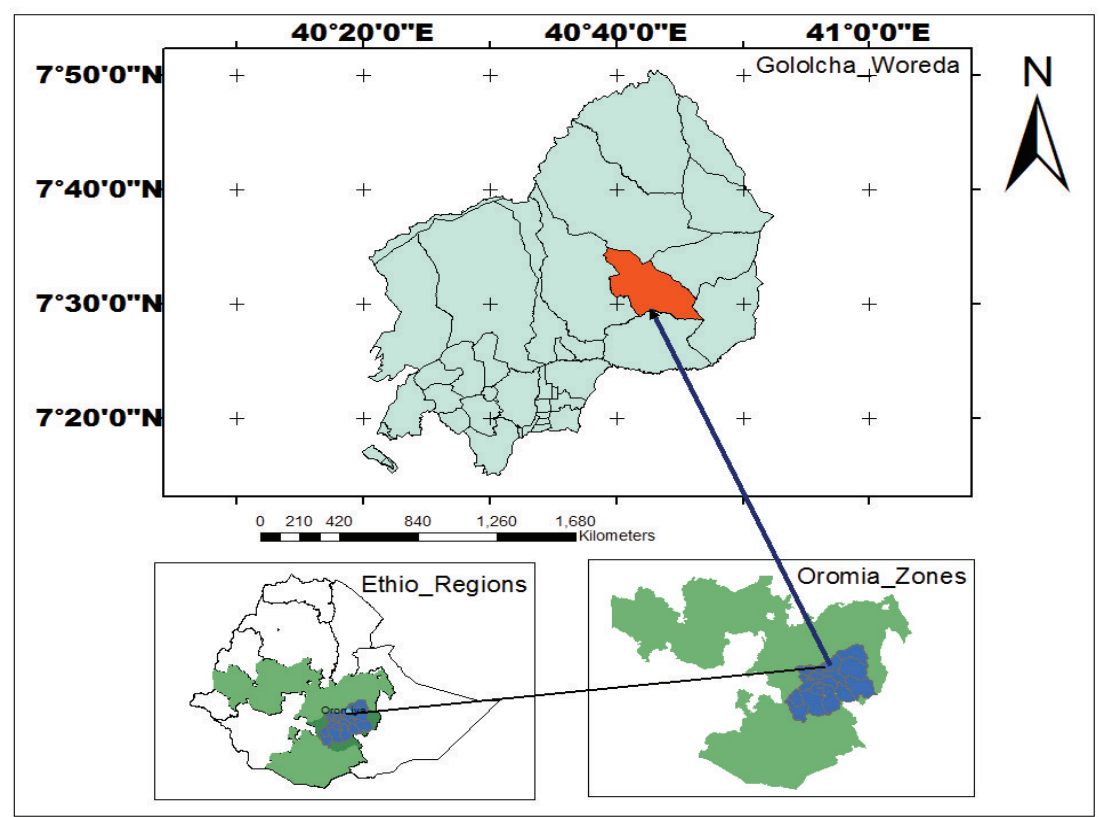

Figure 1: Map of the study area (Source: Ethio GIS)

The temperature and rainfall data were collected from Gololcha Agriculture and Rural Development Office which is the nearest weather station for study site. Accordingly, the mean annual temperature of the district is $19^{\circ} \mathrm{c}$. The lowest temperature is $15^{\circ} \mathrm{c}$ and highest is $23^{\circ} \mathrm{c}$ respectively. The mean annual rainfall is 750 $\mathrm{mm}$ whereas the lowest and highest rainfall is $580 \mathrm{~mm}$ and $920 \mathrm{~mm}$ respectively.

The vegetation available in Kubayo forest is dominated by natural vegetation species such as Juniperus procera (Hindheessa), Combretum molle (bika), Acokanthera schimperi(keraru), Olea europaea (Ejersa), Cordia africana (wadesa), Maytenus arbutifolia (kombolcha), Croton macrostachyus (bakkanniisa), Podocarpus falcatus (birbirsa) and Acacia abyssinica (Laaftoo).and diverse species of bushes, shrubs and herbs.

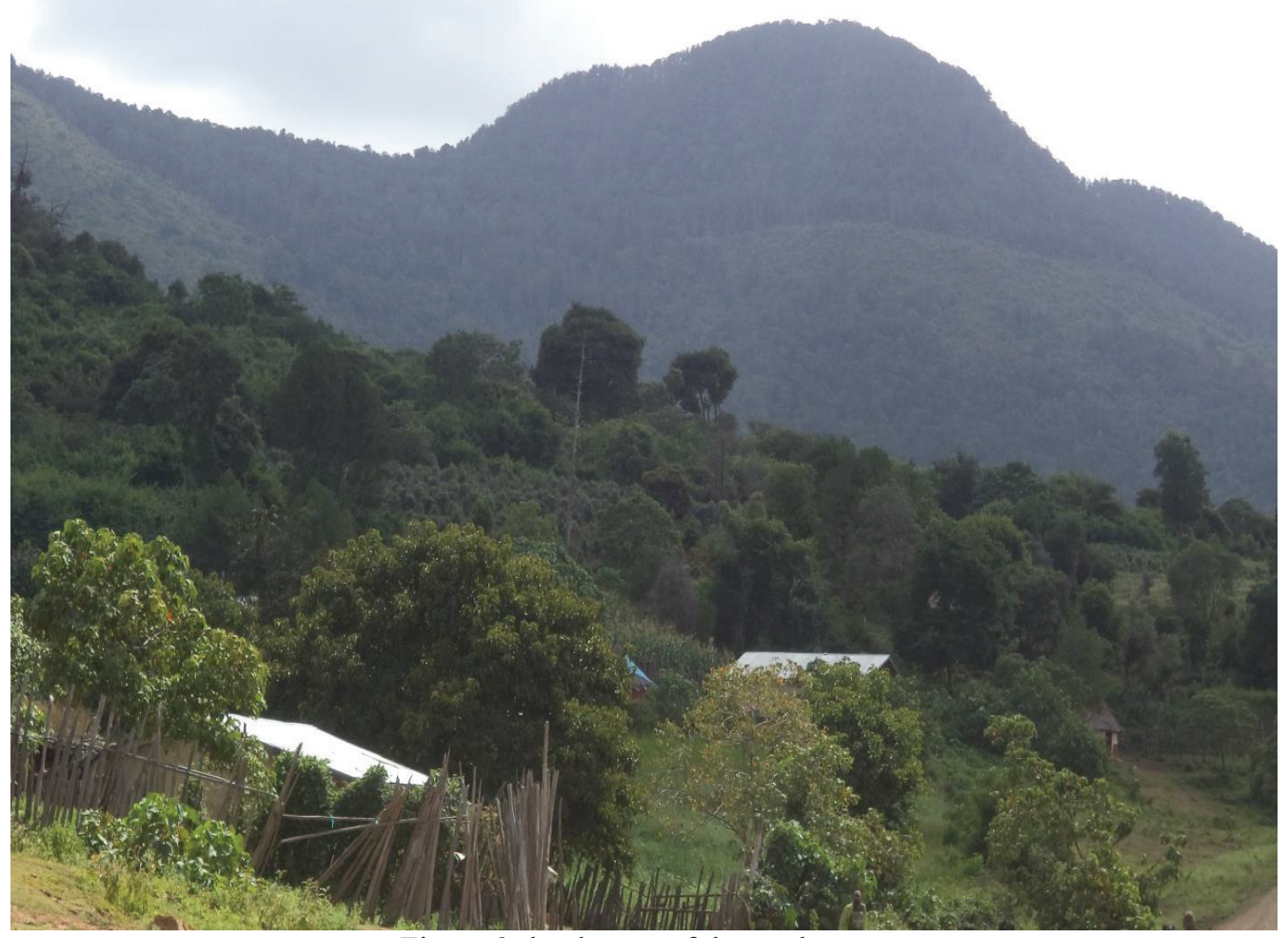

Figure 2: landscape of the study area 


\subsection{Methodology}

The methodology and procedures used to estimate carbon stocks were simple allometric procedures using standard carbon inventory principles and techniques. That is based on data collection and analysis of carbon accumulating in the above-ground biomass, below-ground biomass, leaf litter and soil carbon of forests using verifiable modern methods (Pearson et al., 2005).

\subsection{Delineation and Stratification of the study area}

Delineation of the forest boundaries were the first step in forest carbon stock measurement. The boundary of the study forest area was delineating by taking geographic coordinates with global positioning system (GPS) at each turning point. The GPS points that were taken from the study site to indicate each sample plots were recorded.

Stratification helps in the forest in order to take accurate data from the field, to save time and energy as well as to maintain the homogeneity of the area. Different options can be used for stratifying the study area including land use, plant species, slope, drainage, age of plants, altitude, and proximity to settlement, aspect and position of hill slopes, as stated by Bhishma et al. (2010). For this study, the altitude difference was used. Therefore, the study site were stratified in three categories of altitude i.e., lower, middle and upper (starting from the lowest to the top of the mountain).

\subsection{Sampling design}

The nested quadrat designs which are appropriate for inventories in natural forests, where there is high variability in tree size, distribution and structure (Brown, 1997) were used. Even though, both rectangular and circular nested quadrats are applied in most of the forest carbon measurements, rectangular quadrat is more advantageous and recommended for the study area. This is because rectangular quadrats tend to include more of within-quadrat heterogeneity, and thus be more representative than the circular quadrats of the same area (Brown, 1997; Hairiah et al., 2001).

The rectangular nested quadrat design was used. A transect is set up deliberately across areas where there are rapid changes in vegetation and marked environmental gradients (Kent and Coker, 1992). In general, the more area sampled, the more precise the estimates can be, but at the expense of additional sampling effort. Accordingly, nine transect lines were laid for the selected forest each at an interval from the lower, middle and upper altitude of the mountain. Accordingly seven quadrats from each transects with a total of 63 quadrats of 20 $\mathrm{m} \times 20 \mathrm{~m}\left(400 \mathrm{~m}^{2}\right.$ each) in size was systematically established for carbon stock estimation. As recommended by Brown (1997), a 1mx1m sub plot from each corner and center of rectangular plot was used for sampling soil and litter organic carbon. Quadrats were laid systematically at every $100 \mathrm{~m}$ along transect lines, which is $200 \mathrm{~m}$ apart from each other. In order to eliminate any influence of the road effects on the forest biomass, all the quadrats were lay at least $100 \mathrm{~m}$ away from nearest roads.

\subsubsection{Litter sampling}

The litter samples were collect from sub quadrat of $1 \mathrm{~m} \times 1 \mathrm{~m}$ in each quadrat. From each quadrat at each corner and center of the sub quadrat, samples were taken. All litter samples in the sub quadrats were collected by manual from each sub quadrat 100 gm composite sample was measured for field wet weight and taken for laboratory analysis at Sinana agriculture research center. The litter samples were oven dried at $105{ }^{\circ} \mathrm{C}$ for 48 h using dry ashing method (Allen et al., 1986). Oven-dried samples were taken in pre-weighed crucibles. Then the samples were ignited at $550{ }^{\circ} \mathrm{C}$ for one hour in muffle furnace. After cooling, the crucibles with ash were weighed and percentage of organic carbon was calculated. Finally, carbon in litter ton per hectare for each sample was determined.

\subsubsection{Soil sampling}

The soil samples for soil carbon determination were collected from sample plots laid for litter sampling. In each sub-quadrat one soil sample was taken using core sampler auger at depth of $30 \mathrm{~cm}$ from the four corners and center of each quadrat. The standard depth for SOC is $0-30 \mathrm{~cm}$ (FAO, 2017). Soil sample was mixed homogenously and $100 \mathrm{gm}$ samples were taken from each sample quadrat for the determination of organic carbon in the laboratory using Walkley-Black method. Finally the bulk density, soil organic carbon and soil organic matter were calculated (Pearson et al., 2005).

\subsection{Estimation of Carbon Stocks in Different Carbon Pools 2.5.1. Estimation of above ground carbon stock (AGC)}

The AG biomass consists of all living vegetation above the soil, inclusive of stems, stumps, branches, bark, seeds and foliage. The DBH (at $1.3 \mathrm{~m}$ ) of individual trees with DBH greater than or equal to $5 \mathrm{~cm}$ was measured in each sampling plots. From the different available allometric equations to estimate the above ground biomass, the model that was developed by Brown et al., (1989) is selected for the study site since the general criteria described by the author are similar to the study area. The general equation that was used to calculate the 
above ground biomass is given below:

$$
\mathrm{AGB}=34.4703-8.0671(\mathrm{DBH})+0.6589\left(\mathrm{DBH}^{2}\right) .
$$

Where, AGB is above ground biomass, $\mathrm{DBH}$ is diameter at breast height.

Estimation of above ground carbon content

$$
\mathrm{AGC}=\mathrm{AGB} \times 0.5
$$

Where, $\mathrm{AGC}=$ above ground carbon content

To estimate the amount of $\mathrm{CO}_{2}$ sequestered in the above ground biomass, the above ground carbon has to be, multiplied by 3.67. Because the ratio of $\mathrm{CO}_{2}$ to $\mathrm{C}$ is $(44 / 12)=3.67$

\subsubsection{Estimation of below ground carbon stock (BGC)}

Below ground biomass estimation is much more difficult and time consuming than estimating aboveground biomass (Geider et al., 2001). Roots play an important role in the carbon cycle as they transfer considerable amounts of Carbon to the ground, where it may be stored for a relatively long period of time. As indicated by Mac Dicken (1997), standard method for estimation of below ground biomass can be obtained as $20 \%$ of above ground tree biomass i.e., root to shoot ratio value of 1:5 is used.

The equation is given below:
$\mathrm{BGB}=\mathrm{AGB} \times 0.2$

Where, $\mathrm{BGB}$ is below ground biomass, AGB is above ground biomass, 0.2 is conversion factor (or $20 \%$ of AGB).

For both $\mathrm{AGB}$ and $\mathrm{BGB}$, the biomass stock density was attained in $\mathrm{Kg} / \mathrm{m}^{2}$ by means of dividing the sum of all individual tree biomass $(\mathrm{Kg})$ in a plot by the area of the plot $\left(\mathrm{m}^{2}\right)$. The value was converted to ton/ha by multiplying it by 10 . Since the plot areas are part of tropical region, carbon content in the biomass was estimated by multiplying 0.5 while multiplication factor 3.67 was used to estimate $\mathrm{CO}_{2}$ equivalent (Pearson et al., 2005).

\subsubsection{Estimation of litter biomass}

As stated by Pearson et al. (2005), estimation of the amount of biomass in the leaf litter can be calculated by $\mathrm{LB}=\frac{W \text { field }}{A} * \frac{W_{\text {sub Sample }(\text { dry })}}{W_{\text {sub sample }(\text { fresh })}} * \frac{1}{10000}$

Where: LB $=$ Litter (biomass of litter tha ${ }^{-1}$ )

$\mathrm{W}$ field = weight of wet field sample of litter sampled within an area of size $1 \mathrm{~m}^{2}(\mathrm{~g})$;

$\mathrm{A}=$ size of the area in which litter was collected (ha);

$\mathrm{W}$ sub-sample, dry = weight of the oven-dry sub-sample of litter taken to the laboratory to determine moisture content $(\mathrm{g})$, and

$\mathrm{W}$ sub-sample, fresh = weight of the fresh sub-sample of litter taken to the laboratory to determine moisture content $(\mathrm{g})$.

The percentage of organic carbon storage from the dry ashing in the litter carbon pool was calculated as follows (Allen et al., 1986):

$$
\begin{aligned}
& \% \text { Ash }=\frac{W_{c}-W_{a}}{W_{b}-W_{a}} * 100 \\
& \% \mathrm{C}=(100-\% \text { Ash }) * 0.58 \text {. } \\
& \text { Where, } \mathrm{C}=\text { organic carbon }(\%) \\
& \mathrm{Wa}=\text { the weight of the crucible }(\mathrm{g}) \\
& \mathrm{Wb}=\text { the weight of oven dried grind samples and crucibles }(\mathrm{g}) \\
& \mathrm{Wc}=\text { the weight of ash and crucibles }(\mathrm{g}) \\
& \mathrm{CL}=\mathrm{LB} \times \% \mathrm{C} \\
& \text { Where, } \\
& \mathrm{CL} \text { is total carbon stocks in the litter in ton/ha, } \\
& \% \mathrm{C} \text { is carbon fraction determined in the laboratory (Pearson et al., 2005). }
\end{aligned}
$$

The litter carbon has to be multiplied by 3.67 to get the amount of $\mathrm{CO}_{2}$ sequestered in litter biomass.

\subsubsection{Estimation of soil organic carbon}

The carbon stock density of soil organic carbon can be calculated as recommended by Pearson et al. (2005) from the volume and bulk density of the soil.

$$
V=h X \pi r^{2}
$$

Where, $\mathrm{V}$ is volume of the soil in the core sampler augur in $\mathrm{cm}^{3}, \mathrm{~h}$ is the height of core sampler augur in $\mathrm{cm}$, and $\mathrm{r}$ is the radius of core sampler augur in $\mathrm{cm}$ (Pearson et al., 2005). More over the bulk density of a soil sample can be calculated as follows: 


$$
B D=\frac{W_{a v}, d r y}{v}
$$

Where, BD is bulk density of the soil sample,

Wav, dry is average air dry weight of soil sample per the quadrat,

$\mathrm{V}$ is volume of the soil sample in the core sampler auger in $\mathrm{cm}^{3}$ (Pearson et al., 2005)

$$
S O C=B D * D * \% C
$$

Where, $\mathrm{SOC}=$ soil organic carbon stock per unit area $\left(\mathrm{t} \mathrm{ha}^{-1}\right)$

$\mathrm{BD}=$ soil bulk density $\left(\mathrm{g} \mathrm{cm}^{-3}\right), \mathrm{D}=$ the total depth at which the sample was taken $(30 \mathrm{~cm})$, and $\% \mathrm{C}=\mathrm{Carbon}$ concentration (\%).

\subsubsection{Estimation of total carbon stock of the area}

The carbon stock density is calculated by summing the carbon stock densities of the individual carbon pools of the stratum using the Pearson et al. (2005) formula. In addition, it is recommended that any individual carbon pool of the given formula can be ignored if it does not contribute significantly to the total carbon stock (Bhishma et al., 2010).

\subsubsection{Carbon stock density of a study area:}

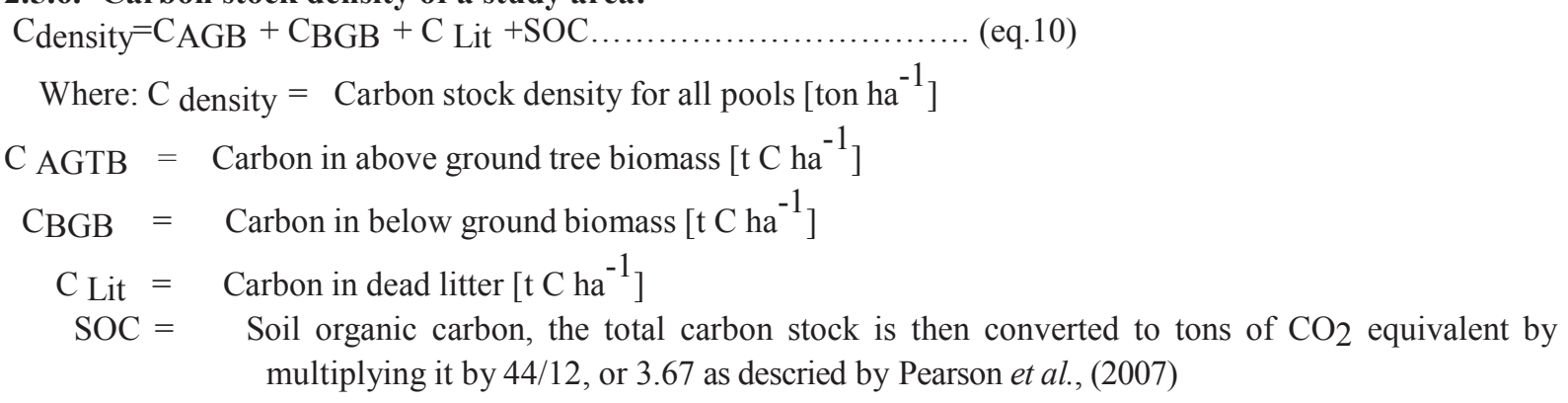

\subsection{Statistical Analysis}

The environmental and various carbon pools data gathered from the field was fed into a computer and organized on the excel data sheet for the subsequent analysis of the data. After recording and organizing data, the quantitative analysis were made using Microsoft excel of 2010 and Statistical Package for Social Science (SPSS) software version 20. Based on the collected data (DBH, fresh and dry weights of litter and soil organic matter), biomasses of each tree species in all sample quadrats were calculated by using developed allometric model and converted in to quadrat and hectare base by using conversion factor. The relationship between different parameter was tested by linear regression and One Way ANOVA.

\subsection{LIMITATIONS OF THE STUDY}

Because of the limited time and available resources, the sample area is relatively small compared to overall forest cover and the selected allometirc equations themselves have their own limitation when applied to different forest type. However it is important for contributing basic information which helps sustainable forest management to mitigate the raising tides of climate change.

\section{RESULTS AND DISCUSSION}

\subsection{Results}

\subsubsection{Above ground biomass (AGB)}

The biomass estimation method was used to determine the biomass and the carbon stock of the tree in the study site known as Kubayo forest. The result shows that the maximum and minimum above ground biomass (AGB) was 345.06 and 162.07 ton/ha respectively. The average AGB stock of the study site was recorded 282.11 ton/ha.

\subsubsection{Below ground biomass (BGB)}

As shown in the above figure the value of below ground biomass (BGB) depends on the result of above ground biomass (AGB), which is $20 \%$ of it. The maximum and minimum value was 69.01 and 32.41 ton/ha respectively. The average biomass stock was $56.42 \mathrm{ton} / \mathrm{ha}$. The graphical representation of the biomass of each plot is shown as the following figure. 


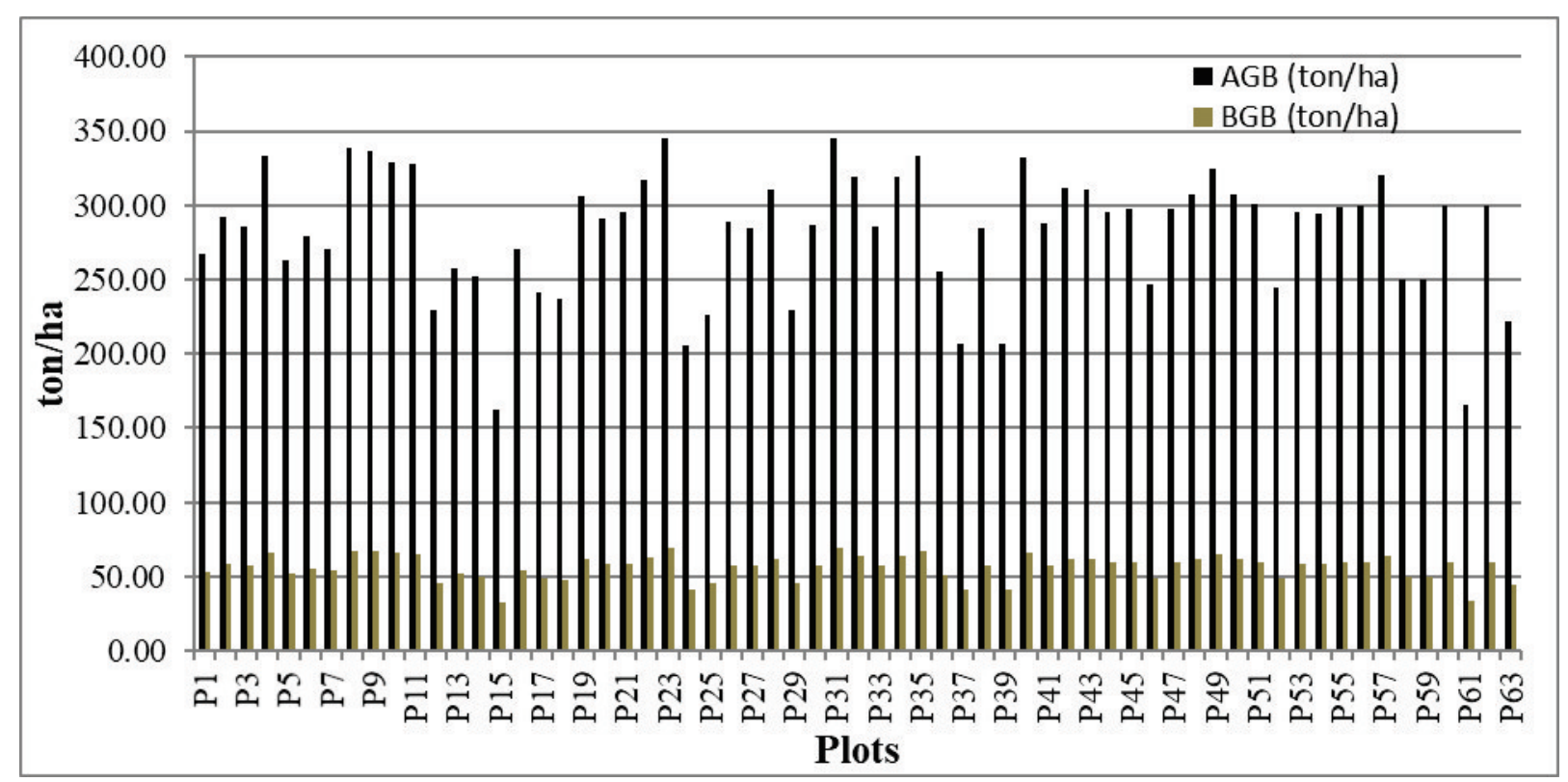

\subsubsection{Litter biomass (LB)}

Figure 3: Above ground and below ground biomass vs Plots

The litter biomass of the study area shows some variation between plots and based on this the maximum and minimum value of the litter biomass were 0.0896 and 0.0159 ton/ha respectively. The average biomass stock of the study site was 0.0608 .

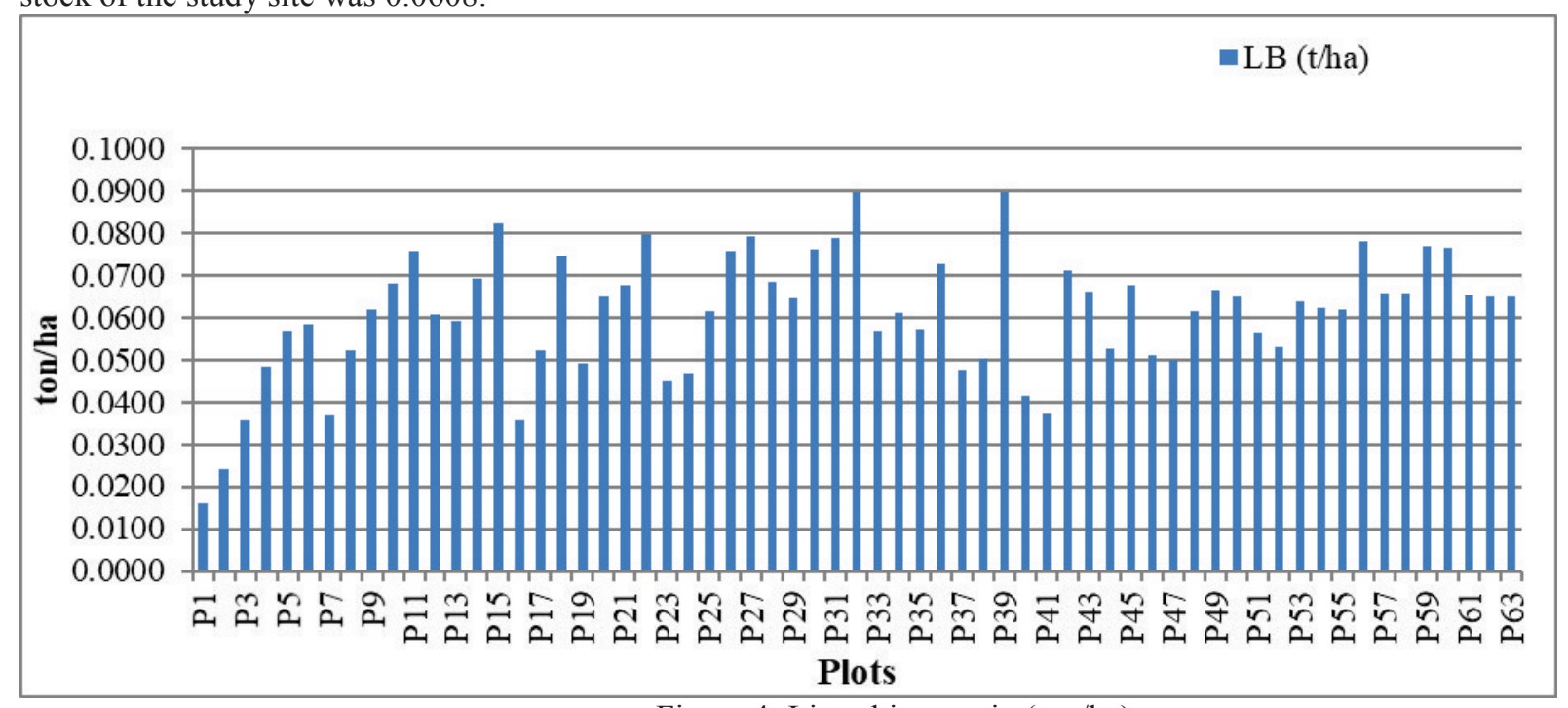

Figure 4: Litter biomass in (ton/ha)

\subsection{Carbon stocks in different carbon pools}

\subsubsection{Carbon stock in above ground biomass (AGC)}

The maximum and minimum above ground carbon stock potential of Kubayo forest was 172.53 and 81.03 ton/ha respectively. The mean above ground carbon stock of the study area was 141.06 ton/ha. The maximum and minimum AG carbon dioxide $\left(\mathrm{CO}_{2}\right)$ sequestration of the study site was 633.18 and 297.40 ton/ha respectively. The mean above ground $\mathrm{CO}_{2}$ sequestration of the study area was 517.68 ton/ha) Figure 5 . 


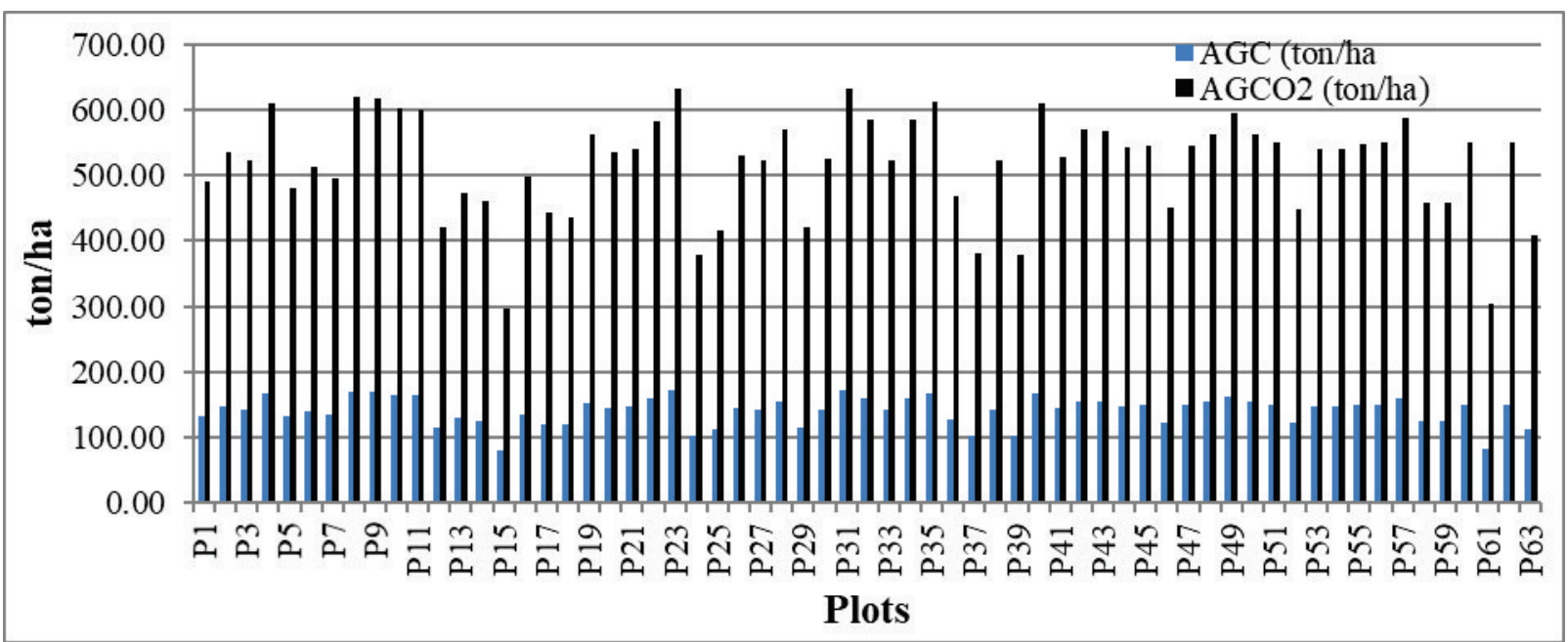

\subsubsection{Carbon stock in below ground (BGC)}

Figure 5: $\mathrm{AGC}$ and $\mathrm{AGCO}_{2}$ vs plots

The biomass of below ground helps to determine the carbon stock of the study area. Based on the study result, the maximum and minimum value of carbon sequestered in below ground biomass was 34.51 and 16.21 ton/ha respectively. The mean value of below ground carbon stock was 28.21 ton/ha. The maximum and minimum carbon dioxide sequestration of below ground biomass of the study area was 126.64 and 59.48 ton/ha respectively. The average carbon dioxide sequestration of below ground biomass was 103.54 ton/ha. The following figure indicates the carbon stock in belowground biomass.

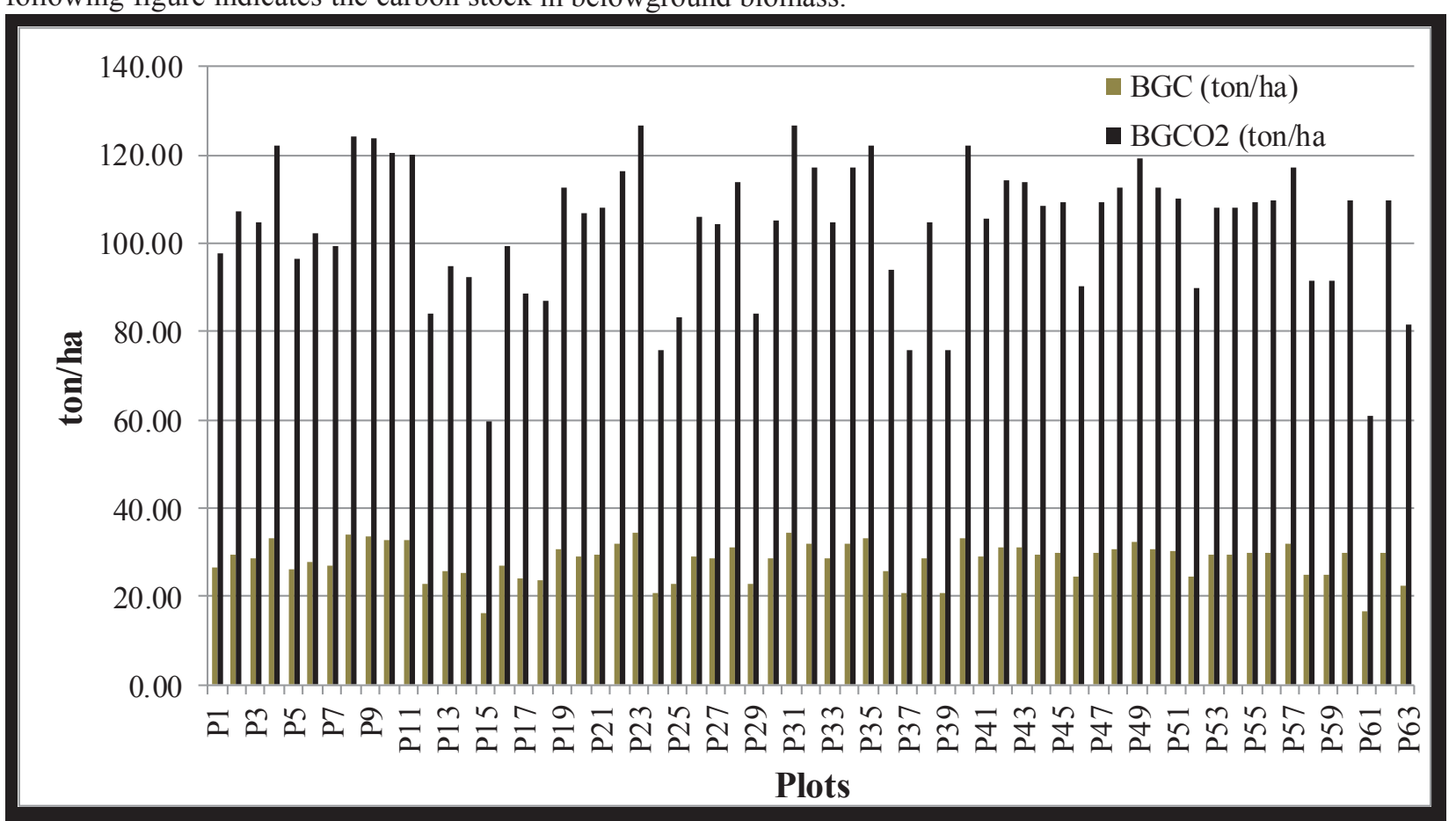

\subsubsection{Carbon stock in litter biomass}

Figure 6: $\mathrm{BGC}$ and $\mathrm{CO}_{2}$ versus Plots

The litter carbon concentration per sample plot in the laboratory analysis was resulted in with the maximum value of 4.05 and the minimum of 0.74 ton/ha respectively. And this condition shows variations within plots. The mean carbon concentration of the study site was 2.65 ton/ha. Carbon dioxide sequestrations of the study site were also resulted in with the maximum and minimum value of 14.87 and 2.70 ton/ha respectively, with the mean value of 9.73 ton/ha. 


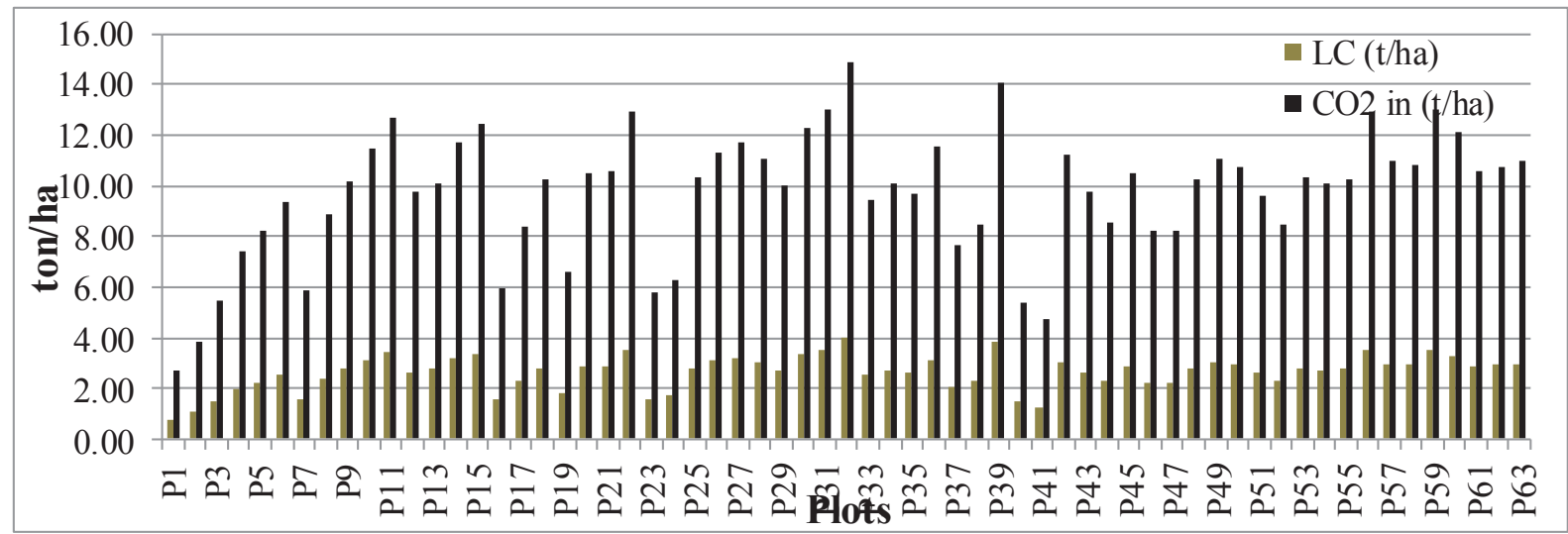

Figure 7: Litter Carbone and Litter $\mathrm{CO}_{2}$ versus Plots

\subsubsection{Estimation of soil organic carbon stock}

From laboratory analyzed results, the soil bulk density ranged from $0.5062 \mathrm{~g} \mathrm{~cm}^{-3}$ of minimum to $1.3170 \mathrm{~g}$ $\mathrm{cm}^{-3}$ of maximum value with mean value $0.7848 \mathrm{~g} \mathrm{~cm}^{-3}$ were at study site. The Maximum and the Minimum value of soil organic carbon stock of Kubayo forest range from 321.42 and 114.32 ton/ha respectively. The mean soil carbon stock of the study site was 198.42 ton/ha. The study site sequestered carbon dioxide with the Maximum and minimum value of 1179.60 and 419.57 ton/ha respectively. The mean soil carbon diode stock of the study site was 728.21 ton/ha.

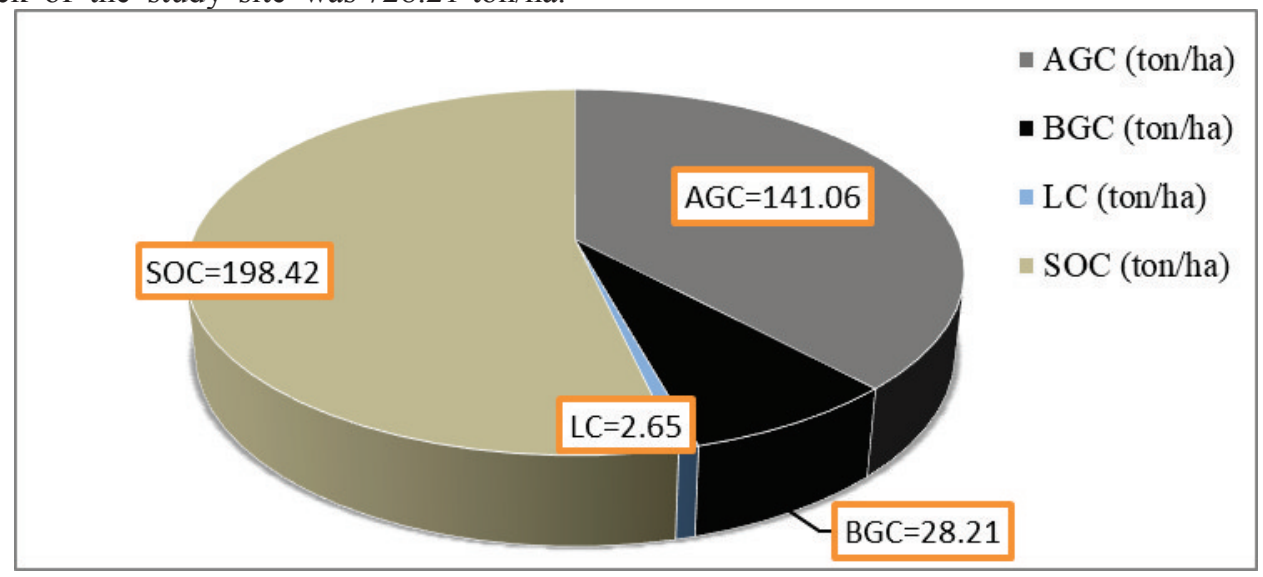

Figure 8: Average carbon stock in different carbon pools

\subsubsection{Total carbon stock of Kubayo forest}

The total carbon stock of Kubayo forest was obtained by adding all carbon value of each pool which revealed (above ground carbon, below ground carbon, liter carbon and soil organic carbon) for the entire sample plots of the study site. As a result of these, the total carbon stock of studied forest ranged about the maximum $532.51 \mathrm{ton} / \mathrm{ha}$ and minimum value of 212.30 ton/ha. The mean carbon stock in all carbon pool of the study site was 370.34 ton /ha (figure 9). The following figure shows the total carbon stock of Kubayo forest. 


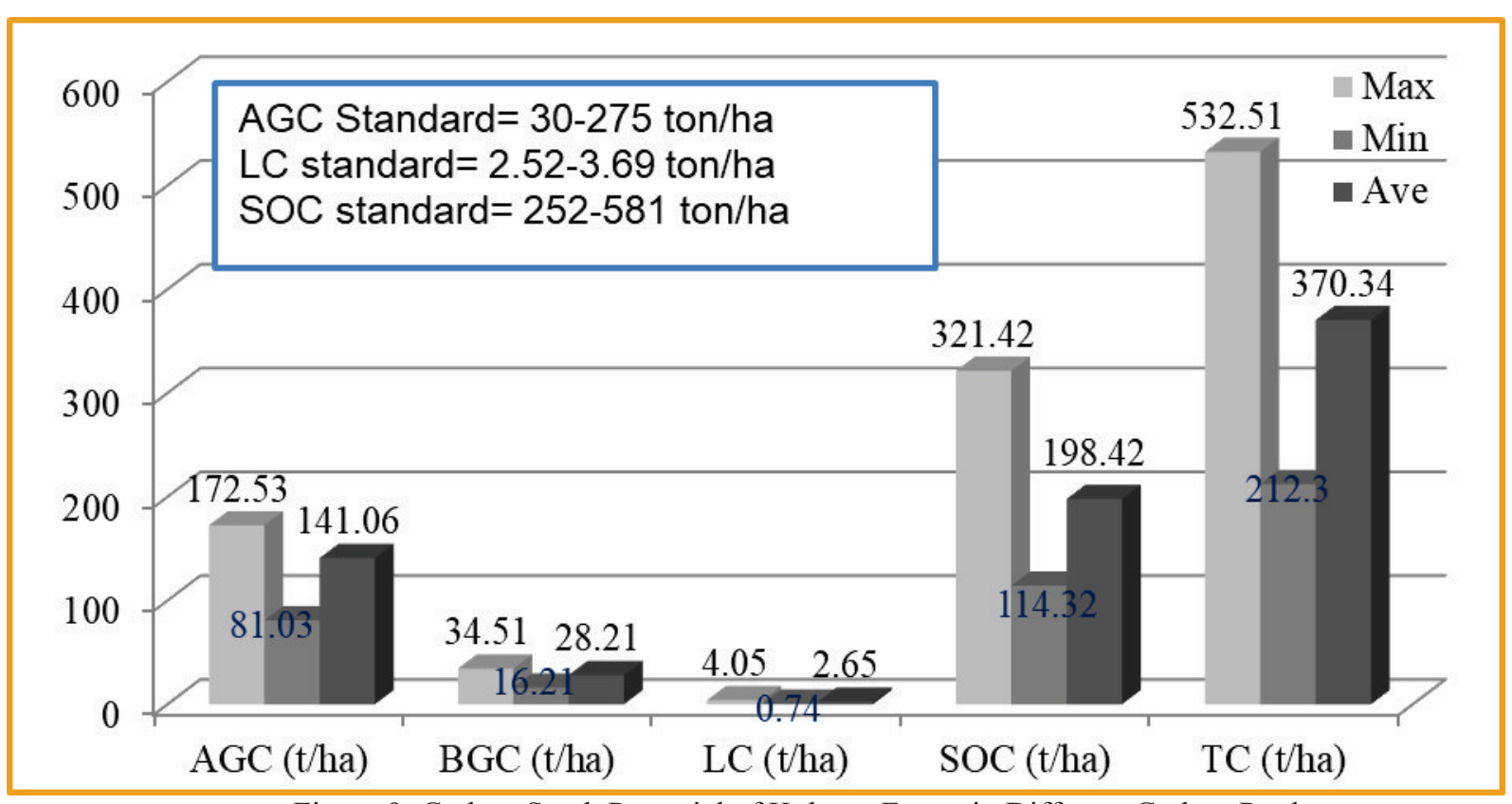

Figure 9: Carbon Stock Potential of Kubayo Forest in Different Carbon Pools

\section{Discussion}

\subsection{Biomass potential of Kubayo forest in different carbon pools}

Forest has a large potential for temporary and long term carbon storage (Houghton, 2001). The maximum and minimum above ground carbon pool was 172.53 and 81.03 ton/ha respectively. The average carbon stock recorded in above ground was also 141.06 ton/ha. Comparing with other recent studies the biomass and carbon stock of the study site (Kubayo forest) was almost proportional with a little bit variation to Yerer Forest (Aregu Balleh, 2015) and Meskel Gedam Forest (Dagnachew Tefera, 2016) an average AGC storage of 140.60 and 146.34 ton/ha respectively. As indicated by Murphy and Lugo (1986), the global AGC in tropical dry and wet forests ranged between 30-275 ton/ha and 213-1173 ton/ha respectively and due to this, the result of the study site had almost a positive carbon stock potential and this indicates the forest status was well managed and protected even if some human interference were there.

The result of carbon stock in litter pool of the present study was 2.65 ton/ha. According to Brown and Lugo (1982), litter fall in dry tropical forests range between 2.52- 3.69 ton/ha. The present study result is comparable to the standard value. The litter quantity and quality varies with tree species and hence for forest types (Lorenz \& Lal 2010; Jandl et al., 2007). When the mean carbon stock in litter pool of this study compared with other similar studies, it was close to Ades Forest (Kidanemariam Kassahun, 2014) and higher than that of the value recorded on Woyramba Forest by Zelalem Teshager in 2017.

The mean bulk density of the forest site was low $\left(0.7847 \mathrm{~g} / \mathrm{cm}^{-3}\right.$, ranging between 0.5062 to 1.3170

$\mathrm{g} / \mathrm{cm}^{-3}$ ) which means that the study area has high organic matter content in the soil as indicated by Brady, (1974). The SOC estimate of Afromontane Rain forests varies between 252 and 581 ton/ha (Munishi and Shear, 2004). The result of present study which is 198.01 ton/ha was lower than this range. The value was also lower than that of Tara Gedam forest (Mohammed Gedefaw et al., 2014), Egdu forest (Adugna Feyissa et al., 2013) and Ades forest (Kidanemariam Kassahun , 2014) of Ethiopia (Table 7). On the contrary, the current value was higher than SOC of Menagasha Suba State Forest (Mesfin Sahile, 2011), Meskele Gedam forest (Dagnachew Tefera, 2016) and Weiramba Forest (Zelalem Teshager, 2017).

Therefore, according to Sheikh et al., (2009) the higher mean SOC stock might be due to the presence of high SOM and fast decomposition of litter which results in maximum storage of carbon stock. Generally, this result indicated that the study area had large carbon stock and sequestered large amount of $\mathrm{CO}_{2}$ contributing significantly to the mitigation of global climate change. Soil organic carbon of the forest depends on not only soil bulk density but also again highly depends on the moisture, decomposition of litter carbon, climatic zone, temperature, slope, altitude, aspect and the nature of soil (Kidanemariam Kassahun, 2014). Overall, the present result revealed that the study forest had high carbon stock and thus sequestered high amount of $\mathrm{CO}_{2}$ contributing to the mitigation of global climate change. 
5. CONCLUSION AND RECOMMENDATIONS

Climate change is a global issue, which needs urgent and practical response. Therefore, based on the present study Kubayo forest has a significant contribution to carbon sequestration to mitigate climate change and therefore can generate carbon credits for Ethiopia. The overall carbon stock potential of the study area varied from one carbon pool to another pool due to unequal distribution of biomass on each plots. The study forest had the potential to store mean carbon stock of 370.34 ton/ha and 1359.15 ton/ha of carbon dioxide equivalent. The average carbon stocks in the forest area were large and the result is comparable to some study results of forests in Ethiopia. This shows the highest contribution of the forest for carbon sequestration and hence mitigation of climate changes.

The following recommendations were forwarded based on the results of the study; the local and regional administrative bodies need to promote sustainable land resource management systems that sustain or increase environmental, social and economic benefits while maintaining the forests long-term services. Particularly, the government should promote the improvement of non-timber products use and eco-tourism would lessen the deforestation rate and promote the reforestation schemes that would in turn help the climate resilient economic development strategy.

\section{Conflicts of Interest}

The authors did not declare any conflict of interest.

\section{Acknowledgement}

This study was carried out with the financial assistance Farm Africa, REDD+ project. Therefore, we are gratitude to Farm Africa for the financial assistances.

\section{REFERENCES}

Adugna Feyissa, Teshome Soromessa and Mekuria Argaw (2013). Forest Carbon Stocks and Varia- tions along Altitudinal Gradients in Egdu Forest: Implications of Managing Forests for Climate Change Mitigation. Science, Technology and Arts Research Journal 2(4): 40-46.

Allen S. E., Grimshaw H. M. and Rowland, A. P. (1986). Chemical analysis. In: "Methods in plant ecology" (Moore, P. D., Chapman, S. B. eds). Blackwell Scientific Publications, London, UK, Pp. 285-344.

Beerling, D.J.; Woodward, F.I. Vegetation and Terrestrial Carbon Cycle: Modeling the First 400 Million Years; Cambridge University Press: Cambridge, UK, 2004.

Bhishma, P. S., Shiva, S. P., Ajay, P., Eak, B. R., Sanjeeb, B., Tibendra, R. B., Shambhu, C., and Ri- jan, T. (2010). Forest Carbon Stock Measurement: Guidelines for measuring carbon stocks in community-managed forests. Funded by Norwegian Agency for Development Cooperation (NORAD). Asia Network for Sustainable Agriculture and Bio resources (ANSAB) publishing, Kathmandu, Nepal, Pp.17-43.

Brown, S. (1997). Estimating Biomass and Biomass Change of Tropical Forests: A primer. UN FAO Forestry paper, Rome 134: 20-55.

Brown, S. and Lugo A. E. (1992). Above-ground biomass estimates for tropical moist forests of the Brazilian Amazon. Interciencia 17: 8-18.

Cairns, M.A., Olmsted, I., Granados, J. and Argaez, J. (2003). Composition and aboveground tree biomass of a dry semi-evergreen forest on Mexico's Yucatan Peninsula. Forest Ecol. Manage. 186: 125-132.

Dagnachew Tefera, (2016). Carbon Stock of Meskele Gedam Forest and its Contribution to Climate Change Mitigation, Semen Shewa, Ethiopia. MSc Thesis (unpublished), Addis Ababa University

EFAP (Ethiopian Forestry Action Program) (1994). Ethiopian Forestry Action Program, Vol. 2. The Challenge for Development. Ministry of Natural Resources Development and Environmental Protection, Addis Ababa.

FAO. (2017). Strengthening Capacity for Climate Change Adaptation in the Agriculture Sector in Ethiopia.

Geider, J.R., Delucia, H.E., Falkowsk, G.P., Finzi, C.A., Grime, P.J., Grace, J., Kana, M.T., Roche, J. (2001). Primary productivity of planet earth: biological determinants and physical constraints in terrestrial and aquatic habitats. Global Change Biology 7: 849-882.

Gibbs HK, S Brown, JO Niles and JA Foley (2007) Monitoring and estimating forest carbon stocks: Making REDD a reality. Environmental Resource Letters 2: 1-13.

IPCC (2000). IPCC Special Report on Land Use, Land-Use Change and Forestry. A special report of the Intergovernmental Panel on Climate Change. Approved at IPCC Plenary XVI (Montreal, 1-8 May, 2000). IPCC Secretariat, c/o World Meteorological Organization, Geneva, Switzerland. At http:/www.ipcc.ch/ IPCC, Land Use, Land-Use Change, and Forestry, A Special Report of the Intergovernmental Panel on Climate Change, Cambridge, UK, 2000.

IPCC (2001). Climate Change 2001: Impacts, Adaptation and Vulnerability. IPCC Third Assessment Report. Intergovernmental Panel on Climate Change. IPCC Secretariat, c/o World Meteorological Organisation, Geneva, Switzerland. At http://www.ipcc.ch/ 
IPCC (2006). IPCC Guidelines for National Greenhouse Gas Inventories. National Greenhouse Gas Inventories Program, IGES, Japan.

IPCC (2007). Climate Change 2007: Impacts, Adaptation and Vulnerability. Contribution of Working Group II to the fourth assessment report of the Intergovernmental Panel on Climate Change. Cambridge University Press, Cambridge, U.K. ; New York.

Jandl, R., Rasmussen, K., Tomé, M. and Johnson, D.W. (2007). The role of Forests in carbon Cycles, Sequestration and Storage. Issue 4. Forest management and carbon sequestration. Federal Re- search and Training Centre for Forests, Natural Hazard and Landscape (BFW), Vienna, Austria.

Kang, S. M., I. M. Held, D. M. W. Frierson, and M. Zhao, (2008). The response of the ITCZ to extra tropical thermal forcing: Idealized slab-ocean experiments with a GCM. Journal of Climate, 21 (14), 3521-3532.

Kidanemariam Kassahun (2014). Forest Carbon Stock in Woody Plants of Ades Forest and its Variation along Environmental Factors: Implication for Climate Change Mitigation, at Western Hararghe, Ethiopia. M.Sc. Thesis (Unpublished). Addis Ababa University, Addis Ababa.

Kirschbaum, M.U.F. (1996). The carbon sequestration potential of tree plantations in Australia. In: (eds.), Environmental Management: The Role of Eucalypts and Other Fast Growing Species, Eldridge, K.G., Crowe, M.P., Old, K.M. Forestry and Forest Products, 20:77-89.

Lorenz, K. \&Lal, R. (2010).Carbon Sequestration in Forest Ecosystems, Dordrecht: Springer Netherlands.

MacDicken, K. G. 1997. A Guide to Monitoring Carbon Storage in Forestry and Agro- forestry Projects. In: Forest Carbon Monitoring Program. Winrock International Institute for Agricultural Development, Arlington, Virginia.

Mesfin Sahile (2011). Estimating and Mapping of Carbon Stocks based on Remote Sensing, GIS and Ground Survey in the Menagesha Suba State Forest. M.Sc. Thesis, Addis Ababa University, Addis Ababa.

Mohammed Gedefaw, Teshome Soromessa and Satishkumar Belliethathan (2014). Forest carbon stocks in woody plants of Tara Gedam forest: Implication for climate change mitigation. Sci. Technol. Arts Res. J. 3(1): 101-107.

Pearson, T., Walker, S. and Brown, S. 2005. Sourcebook for land-use, land-use change and forestry projects. Winrock International and the Bio-carbon fund of the World Bank. Arlington, USA, pp. 19-35.

Sheikh, M. A., Kumar, M., Rainer, W. and Bussmann, R. W. (2009). Altitudinal variation in soil or- ganic carbon stock in coniferous subtropical and broadleaf temperate forests in Garhwal Hi- malaya. Department of Forestry, HNB Garhwal University, Srinagar Garhwal, Uttarakhand, India. Carbon Balance management 4 : 1-6.

UNFCCC (2009). The Greenhouse Effect and Carbon Cycle. Essential Background section, United Nations Framework Convention on Climate Change (UNFCCC) Official Website, available at www.unfccc.int, accessed on November 11, 2018.

van der Werf, G. R. Morton, D. C., DeFries, R. S., Olivier, J. G. J., Kasibhatla, P. S., Jackson, R. B., Collatz, G. J. and Randerson, J. T. (2009). 'CO2 emissions from forest loss', Nature Geoscience 2, 737-738.

Yitebitu Moges, Zewdu Eshetu and Sisay Nune. 2010. Manual for assessment and monitoring of carbon in forest and other land uses in Ethiopia (Draft). Addis Ababa, Ethiopia.

Zelalem Teshager, (2017). Woody Species Composition, Structure, Diversity, Regeneration and Carbon Stock in Weiramba Forest, Habru District, Northern Ethiopia. MSc Thesis (unpublished), Addis Ababa University. 